\title{
PHILOSOPHY
}

\section{METHODOLOGY OF PHILOSOPHICAL HERMENEUTICS IN THE SOCIAL SCIENCES}

\author{
V. O. Dubinina \\ Ukrainian Medical Stomatological Academy, Poltava, Ukraine
}

DOI: https://doi.org/10.31435/rsglobal_sr/28022019/6366

\section{ARTICLE INFO}

Received 11 December 2018

Accepted 19 February 2019

Published 28 February 2019

\section{KEYWORDS}

philosophical hermeneutics, applied research,

hermeneutic circle,

self-understanding,

inversion,

hermeneutical reduction.

\begin{abstract}
The purpose of the paper is to determine the key strategies for applying the methodology of philosophical hermeneutics in social sciences, which is realized in solving of the following tasks: 1) to determine theoretical conditions for the turn of philosophical hermeneutics towards applied social research; 2) to identify key concepts and techniques of philosophical hermeneutics, relevant to the measurement of actual social phenomena; 3 ) to outline the logic of application of the elements of philosophical hermeneutics within social science. Methodology of the research is formed by methods of immanent critique of philosophical discourse, adapted to the subject horizon of social studies. Scientific originality of the paper is expressed in the following statements: 1) the theoretical conditions for the applied turn of philosophical hermeneutics include the pragmatic critique of ontologization of the hermeneutic circle, that is, the reinterpretation of philosophical hermeneutics contrary to the key guidelines of its founders (M. Heidegger, H.-G. Gadamer); 2) key concepts and techniques of philosophical hermeneutics, relevant to the measurement of actual social phenomena, are the hermeneutic circle and self-understanding, hermeneutical reduction and destruction; 3) the logic of the applied use of the elements of philosophical hermeneutics in the context of social science involves correlation of the structure of the research with the hermeneutic structure of self-understanding, inherent in the subject under investigation. Conclusion: The study of the conditions of the applied turn of philosophical hermeneutics proved the fundamental importance of setting the problem of the synthesis of fundamental and applied science.
\end{abstract}

Citation: V. O. Dubinina. (2019) Methodology of Philosophical Hermeneutics in the Social Sciences. Science Review. 2(19). doi: 10.31435/rsglobal_sr/28022019/6366

Copyright: (C) 2019 V. O. Dubinina. This is an open-access article distributed under the terms of the Creative Commons Attribution License (CC BY). The use, distribution or reproduction in other forums is permitted, provided the original author(s) or licensor are credited and that the original publication in this journal is cited, in accordance with accepted academic practice. No use, distribution or reproduction is permitted which does not comply with these terms.

\section{Relevance of the research topic.}

The birth and development of modern science is defined by the essential contradiction between the teleological and empirical principles of knowledge development. One of the manifestations of this basic contradiction is the opposition between knowledge as an understanding and knowledge as an explanation, which finds a concrete expression in the confrontation of the key intellectual directions of that or this era. The development of science stimulates the search for resources for the reconstitution of philosophizing, which sometimes leads to a principled contrast between philosophy and science. Philosophic hermeneutics grows out of a rather radical contrast to philosophy and science and the emphasis on the autonomy of philosophizing as a separate form of intellectual existence. Such a statement is typical for the thinking of M. Heidegger and H.-G. Gadamer. Less radical versions of the 
development of philosophical hermeneutics point to the possibility of interdisciplinary application of the results of philosophical-hermeneutical analytics, but they do not clearly define the applied direction of such synthesis and the scientific instrumentalisation of philosophizing.

The applied turn of philosophical hermeneutics is a separate task in solving the fundamental problem of the philosophical community, which is to reconstruct philosophy in the general system of scientific process. After all, in many contexts the expediency of philosophizing solely grows out of the normativity of tradition, and not from the need for means to resolve actual contradictions of relevant processes. That is, here we are dealing with the need for an applied turn of fundamental research in general.

Within the Ukrainian context, philosophical hermeneutics is one of the best-developed areas. A. Bogachev, V. Kebuladze, A. Dakhniy, V. Okorokov are appealing to the development of philosophical-hermeneutical problems. The philosophical-hermeneutical line expressive in the actual translation and, first of all, historical and philosophical studios. As the basis for the development of philosophical theorizing, hermeneutics should be comprehended in the horizon of applied pragmatics.

\section{The purpose of the study.}

The purpose of the research is to determine the conditions for the use of concepts and techniques of philosophical hermeneutics in applied researches of social phenomena. The purpose of the research is specified in the following tasks: 1) to determine the theoretical conditions for the implementation of the applied turn of philosophical hermeneutics; 2) to identify key concepts and techniques of philosophical hermeneutics, relevant to the measurement of actual social phenomena; 3) outline the logic of the applied use of the elements of philosophical hermeneutics in the context of social research.

\section{Presentation of the main material.}

Theoretical conditions for the implementation of the applied turn of philosophical

\section{hermeneutics.}

An overview of actual literature on philosophical hermeneutics shows the existence of significant differences in the synthesis and evaluation of this intellectual paradigm. The emergence of these differences is connected as with global factors - the so-called "analytical continental division" of the modern philosophical process, as with the specific conditions and signs of the development of local philosophical communities, for example, the historical and philosophical dominant in the Ukrainian reception of philosophical hermeneutics. The globalization of scientific communication now puts forward the imperative of identifying its own original position on the subject of research, the relevant inventory of the method and means of research, the explicit solution of the dialectical tension between the global dimension of the philosophical process and the specific particularity of the ideology of its thought. The rejection of such identification, of course, is possible at the level of individual research, but at the level of the intellectual community appears to be a step towards self-isolation.

The particularity of the philosophical process in Ukraine directly correlates with the key issue of Ukrainian society in general, which is to fully integrate into the community of democratic societies. Integration into a particular system of intellectual exchange involves the reception of existing conceptual forms in this system. The structure of receptive activity combines visible or articulated elements with hidden elements. It is these hidden assumptions and preconditions that form the ideological element of the preconditions of perception, which can be called the dispositiv of the reception in the Fulcestinian key.

Philosophical hermeneutics is one of the most attractive intellectual traditions for Ukrainian researchers. In the context of the anthropological orientation of Ukrainian philosophy, the trends of philosophical existentialism and phenomenology, which hermeneutics joined. The domination of two lines of study is historical and philosophical reconstruction and thematic-conceptual development. Within the historical and philosophical reconstruction, the hermeneutic motives of philosophizing are sufficiently investigated. F. Schleiermacher, W. Dilthey, M. Heidegger, H.-G. Gadamer, P. Ricœur. In the context of thematic-conceptual development, the attention of researchers attracts categories of understanding, meaning, experience, hermeneutic circle, etc. The separation of philosophical hermeneutics as an autonomous unit in the system of philosophical sciences also testifies to the development of individual academic disciplines (A. Bogachev).

In the exploration of such researchers as A. Bogachev, A. Dakhniy, V. Kebuladze, V. Shevchuk, studies of phenomenology and hermeneutics are directed on the internal radius of philosophical thought - on the question of ontology and the history of philosophy: "The question of the relationship correlation of between and the history of philosophy is one of the main quesions in 
philosophical knowledge. In our case, it specifies, on the one hand, by the question of the representation of phenomenology and hermeneutics in the studies of the history of their origin and development. On the other hand, it concretizes by the question of the possibility of using phenomenology and hermeneutics as historical and philosophical methods" [4, p. 138]. So outlines the horizon of his own historiographical study of the Ukrainian reception of phenomenology and hermeneutics by V. Kebuladze and he focuses on the external radius of touching philosophy with other sciences rather fragmentarily, focusing on branches of literary criticism and history. Although the careful reading of references can point to the logic of the reception of European historiography and the evolution of philosophical hermeneutics. V. Kebuladze states: "In Ukrainian humanities, we also find attempts to apply some of the tools of phenomenological and hermeneutic methods in the study of history and literature. Thus, in the article "Latent Sensory Structures in Russian History, Philosophy and Literature", the author of these lines, using the notion "latent sense structure" of "objective hermeneutics" of the German socialist researcher Ulrich Overman, is trying to interpret the most important events of Russian history and some key subjects of Russian philosophy and literature in the context that it is formed by the meaningful structures of the eternal city and sacrifice" [4, p. 138]. Immanent logic of philosophical hermeneutics, written by M. Heidegger and G.-G Gadamer. In contrast to the positivist program of sociology, opposes the principles of Ukrainian philosophical discourse, where objective hermeneutics is directed primarily to history and literature, and not to actual practices and institutes, and the sociological dimension of the evolution of the hermeneutic method is ignored and degraded by almost speculative issues.

Similarly, the fundamental work of A. Bogachev, "The Meaning and the Experience" (2011), is based on the emphasis on the philosophical approach to hermeneutics, which is opposed to the scientific method of knowing: "When we interpret meaning, we realize that life behind it is the thought and will of the individual or community ... Instead, objectivistic, natural science explores its subject with the belief that knowledge only manifests the real laws ... Further, in the study, the term understanding will mean hermeneutic, concrete experience, which differs from the abstract, scientific experience often interpreted in philosophical literature as an explanation or cognition" [2, p. 10]. Such logic complicates the use of interesting and valuable works of Ukrainian philosophers and historians of philosophy outside the speculative, from the general scientific point of view, the problems of philosophy itself. Over the past decades, social science put the study of subjectivity at a level close to philosophical self-knowledge.

Even at the level of historiography in the English-language scientific discourse, for example, they use a more flexible terminological apparatus, which allows us to trace the evolution of the scientific study of hermeneutics: "It is possible to distinguish the following modern scientific directions of hermeneutics: conservative hermeneutics, critical hermeneutics and philosophical hermeneutics" [7, p. 171]. Separation of philosophical hermeneutics as such an evolutionary hermeneutic thinking provides an opportunity to sharpen the differences between hermeneutic approach in the wider context than purely philosophical. Such a broad understanding of hermeneutics is derived from the main outcome of Heideggers attempts to ontologize hermeneutics - the universalization of hermeneutic experience. As a result of rooting universal understanding of hermeneutics, its characteristic emphasis on subjectivity and intersubjectivity structures received development in social studies. Directions of application elements of such philosophical hermeneutics in applied social studies constitute professional pedagogical studies (A. Sloan, B. Bowe), humanities studies (M. Beetz, T. Franzheld), clinical studies (P. Regan). Even the initial analysis of the abovementioned explorations illustrates the general application in the logic of the applied adaptation of elements of hermeneutics, which consists in reinterpreting hermeneutics as a qualitative method of social experimentation. The promise of hermeneutics that attracts social scientists, refers to overcome the distance between object and subject of research and the need for small and precise method of providing self-criticism, prejudice tools disavowal of the subject of research.

The aggravation of crisis phenomena in the life of Ukrainian society gives impetus to actualization of practical decisions in the context and theoretical activities. This pragmatics of applied reinterpretation meets the key challenges of today.

Previous attention to phenomenology, hermeneutics and existentialism was motivated by the search for new foundations and constitutive imperatives of philosophy, caused by the rejection of the principles of Soviet philosophy. The demand for means and ways of rethinking the underlying concepts 
and issues has highlighted the extremely high attention to ontology and metaphysics. The overwhelming majority of researches relate the historical-philosophical and thematic-conceptual aspects of the philosophical experiment, leaving without due attention the key in our opinion, dimension of philosophizing - the application of the philosophical method to the actual contemporary contradictions.

Within this exploration we will try to combine the historical and philosophical excursion to the evolution of the "hermeneutic turn" of M. Heidegger's philosophizing with the analysis of the possibility of instrumentalization the elements of philosophical hermeneutics by the qualitative methodology of modern social sciences.

Key concepts and techniques of philosophical hermeneutics in the measurement of actual social phenomena.

It is known that historically hermeneutics was formed as a practice of interpreting legal and sacred texts and had a mediated relationship to philosophy. However, the critique of the possibility of objective knowledge of reality, carried out by I. Kant, revealed the effectiveness of the transcendental structures of construction and the laying the meaning as determinating the forms of knowledge. Understanding the function of knowledge has become its basis.

F. Schleiermacher was one of the first who pointed out that hermeneutic thinking is a universal and organic element of social existence of man, and not a set of strategies for the interpretation of the text. However, as D. Shevchuk rightly observes: "Hermeneutics for F. Schleiermacher, despite his striving for universalization, remains art, and not science, with the general principles and categorical apparatus inherent in it" [5].

Philosophical hermeneutics has grown in the struggle against the reductions of methodology characteristic of modern scientific thinking. H.-G. Gadamer notes in the introduction to the treatise "The Truth and Method": "Thes by its very historical origin, the problem of hermeneutics goes beyond what it establishes the concept of a method, as it has developed in modern science. Understanding and interpreting texts is a task not only of science itself, but with all its obviousness belongs to the totality of human experience of the world in general" [8, p. 7]. The division between the science of nature and the science of the spirit has been adopted here as a basis, and philosophy has been granted the exclusive right of theorizing about the "totality of human experience of the world as a whole." That is, philosophy preserves the status of science of science, a unique topos, where science can be the object of a variety of procedures for the interpretation and evaluation of methods other than the procedures of scientific verification.

During the last century, philosophers managed to maintain this position of critics of science, although the last one unceasingly regained this space of territorialization of philosophical thought. At present, there is a need for the latest ontological synthesis, such as Heidegera's fundamental ontology, which would renormalize the relationship between philosophy and other sciences. Despite the bold development in this direction (A. Badiou), philosophy remains a combination of diverse and often mutually exclusive concepts, equipped with its own conceptual apparatus and specific syntax. Such an interval variety of styles and approaches extremely complicates the reception of philosophical ideas in other scientific contexts, even of a contiguous nature.

Philosophy has an extremely important experience in mastering the concepts and methods of other sciences. However, today the question of moving in the opposite direction - from philosophy to other sciences - breaks up. In the absence of a normative or ideological foundation philosophers have to prove their effectiveness in an applied way.

Historical and philosophical reconstructions of the concept of hermeneutics in the philosophy of M. Heidegger usually refer exclusively to the treatise "Being and time" (1927), in particular those paragraph where the author identifies philosophy with ontology, ontology with phenomenology, and phenomenology with hermeneutics.

Therefore, materials representing the philosophy of the early Heidegger began to be published only from the beginning of the nineties of the last century, a relatively consistent position regarding the evolution of ideas and style articulated in the treatise is only being formed.

Existential hermeneutics or "hermeneutics there-being" (Dasein) of M. Heidegger suggests to ontologize hermeneutics. Heidegger had the intent to develop the phenomenon of Dasein precisely in the form of hermeneutics. It can also be argued that his philosophy continues the line of hermeneutics of the life of V. Delta.

In the introduction of his book Heidegger defines hermeneutics as "the phenomenon of Dasein," where "Dasein" is characterized as "being, which in its being deals with the very being." 
Traditionally, the concept of "being" means a being, an object, a substance, something that has a constant identity. The notion of "Dasein" means a being that differs from other by meaningful attitudes towards itself and to the world, the totality of understanding and the temporality of existence. The doctrine of being, the basis of which is Dasein, is a special kind of ontology, which Heidegger calls "fundamental". The essence of the "fundamental" ontology should be phenomenology.

The development of ontology as a phenomenology, which reveals the essence of the phenomenon of Dasein through its interpretation - this is the idea of Heidegger. He explains it in the following way: on the one hand, the phenomenon must be understood as "that which manifests itself in itself", that is, as that which is existent. Therefore, from the point of view of the content phenomenology is "the science of the existence of things is - ontology" [9, p. 37]. On the other hand, since the subject of ontology is essentially being, which asks for the meaning of one's existance, the ontological analysis is aimed at the reconstruction of the semantic structure of Dasein, and the phenomenological description takes on the form of interpretation. Heidegger writes: "Phanomenologie des Daseins ist Hermeneutik in der ursprünglichen Bedeutung des Wortes, wonach es das Geschäft der Auslegung bezeichnet [Phenomenology of Dasein is hermeneutics in the original sense of the word, which means the practice of interpretation]" [9, p. 50]. Thus, the "fundamental" ontology of Dasein, which Heidegger calls phenomenology, is hermeneutics of Dasein, aimed at determining its existential structure.

The main issue of such hermeneutics is the question of the "The way of being" of the existence [9, p. 50]. "The way of being" is determined not onthemically, that is, not on the basis of the sum of the properties in which Dasein manifests itself. On the contrary, the kind of existence of Dasein is studied ontologically in order to detect a deep, primary - Heidegger calls it "existential" - the structure of Dasein, which defines all its ontic properties. Heidegger's discourse on hermeneutics gains a specific emphasis: hermeneutics as "the interpretation of being Dasein" focuses on "existential analytics of existence." The purpose is to discover the structure of human subjectivity and, proceeding from it, go to the analysis of other ways of existence of things.

The need for such a formulation of the question Heidegger relates with the need to redefine the foundations of cognition. In doing so, he follows the strategy of criticizing the cognition of I. Kant, that explores the possibilities of cognition, but significantly modifies it. The innovation of his program is to eliminate the primacy of theoretical knowledge in philosophy. This approach contradicts the entire traditional theory of knowledge, including the phenomenology of Husserl and those philosophical currents, which, although acknowledging the experience as a sphere of constitutionality of objectivity, but thus limit its scope of experience to the abstract subject of knowledge. Following Dilt, Heidegger opposes the transcendental subject of cognition of Dasein. Dasein expresses the essence of such a being, which, acting and understanding, is always already find itself in the world and, consequently, has a socio-historical structure. In other words, Dasein expresses the essence of man. Heidegger's analysis of the knowledge conditions suggests starting with the discovery of the structure of cognition, which becomes a particular empirical person. This approach inevitably leads the study beyond the theoretical knowledge. "Being and time" is aimed at revealing the conditions for the possibility of pre-theoretical knowledge.

The key concept that made this issue possible was the hermeneutic circle, the universalization of which allowed Heideggers to emphasize the original nature of scientific thinking, both in the diachronic sense of the history of thought and in the synchronization of the formation of consciousness. The emphasis of the integrity of the semantic order of the world in the middle of which the thinking person finds himself and the authenticity of his own existence as absolute value were the foundation of the ontologization of hermeneutics of a dopredicative meaning. It should be noted that M. Heidegger successfully implemented the hermeneutic degradation of traditional concepts, since it was perceived as the bearer of an alternative view of philosophy in the system of science. The attention of the philosophical community to "Being and time" is a sign of the unity of the intellectual field. Recall that Husserl specifically re-read the treatise in order to find a line of demarcation between his own vision of phenomenology and the Heidegger project, R. Karnap, in turn, followed the debates of Heidegger and Cassirer. Perhaps this was the last time the philosophy had a single conceptual basis. Both Carnap, and Husserl, and Cassirer distinguished from Heidegger's fundamental ontology, reflecting the dangerous intentions of radical opposition of philosophy to science. We must admit that hermeneutics was the constitutive source of the conceptualization of this intention, since it made it possible for a hermeneutic reduction of any statement, placing the last one in the immanent plan of a 
conditional whole, transforming this statement into an element of such a conditional whole. Introduction of hermeneutic reduction to the assertions of the natural sciences, transforms the scientific truth into a private case more general rule of certain practices of understanding, covered in the deeper historical retrospection.

The anti-scientific intension of Heidegger's thinking was interpreted differently by the next generations of philosophers. For deconstructivists, it is constitutive; for adepts of analytic philosophy, it is absurd. However, today the key elements of the hermeneutic reduction of expressions, which correlate with the instrumentalist of critical theory and discursive analytics, are unexpectedly inadvertently demanded in the fields of applied social research.

Separately, we must point out the sociology of science, which often uses philosophical tools to identify implicit elements of the logic of modern scientific cognition.

The revolutionary development of communication and production technologies enhances the dynamics of social processes, changes the nature of the functioning of public institutions, exacerbates the problem of conformity of the research methodology with the subject of cognition.

Perturbation of the external elements of human existence revealed the lack of a common understanding of the very foundations of the formation of individual personality. Modern intellectual culture does not provide an unambiguous answer to the question of the essence of gender, culture, ethnicity, identity. Individual, random, subjective needs an adequate scientific cognition and social sciences seek to know this dimension of human existence by the so-called qualitative methods aimed at the concrete realities of a certain social phenomenon.

Perhaps somewhat paradoxically, but the approach of social sciences to a particular person actualizes the development of philosophical thought.

The latest history of philosophy testifies to a controversy about the relationship of philosophy with natural science. The problematic nature of the epistemological status of philosophy is situationally removed, but it has not yet achieved an unambiguous solution yet.

One of the most powerful philosophical anti-scientific statements of the last century, in which the whole direction of philosophizing has been established up until now, is the project of the fundamental ontology of M. Heidegger, who was able to constitution the philosophical critique of science, not limited to specific questions of epistemology. But in the optics of modern science, philosophizing serves as a separate practice, which must be understood not in opposition to other practices, but in the general integrity of social activity. Such a turn formulates the latest agenda for rethinking the conventional forms of philosophizing. In the light of the above mentioned, the hermeneutic circle and self-understanding appear to be the most sought after social lessons of the concepts of philosophical hermeneutics, and the reception of destruction and further reconstruction of the semantic unity of the world correlates with the needs of sociologists in the hermeneutics of the Other.

The logic of the applied application of the elements of philosophical hermeneutics in the context of social experimentation.

The development of natural science, in terms of philosophy, is a constant war for its own subject. Today it is impossible to imagine that philosophy should answer the questions of all without exception of the properties of being or even the abilities of man and the properties of the human world.

However, the instruments of orthodox science are rather nicer in their use, and the reality of human knowledge always contains an element of uncertainty, structural complication requiring calibration of these tools, taking into account indicators and realities that have not been scientifically investigated.

"History", "culture", "thinking" are the generic concepts aimed at determining the specifics of the world created by man in which man becomes a man. Completeness of content of these concepts is a sign of credible premises of the worldview, which updates them. The contradictions of the Enlightenment project, based on the assumption that the order of coexistence of people can be moved to the premises of rational consciousness, showed the existence of significant barriers not only on the way of obtaining objective knowledge of the nature of things that science performs quite well, but the assimilation of this knowledge in a broad cultural the context of worldview and values.

There is a noticeable tendency to construct theological concepts of secular thinking. A. Badiou makes the generalization that only changed Modern the central concept of the system, God is replaced history. The estimation of Heidegger's ontology as a secular theology is also widespread.

The Weber formula of scientific disappointment of the world grows out of the fundamental destructiveness of scientific knowledge of its non-scientific conceptual foundations. The 
destructiveness of scientific research has led to restrictions on the use of direct experimental research methods in many branches of human studies and makes it necessary to seek alternative solutions. One of these solutions "was the development of a qualitative methodology of social research, which often takes the form of interviews, case studies, research within the community, etc." [14, p. 1293]. Qualitative research relates to specific circumstances and participants in certain situations and processes that do not have quantitative (quantitative) indicators.

The logic of approaching the elements of the conceptual paradigm of philosophical hermeneutics to the instrument of qualitative social experiments involves operations of ontologization of a particular situation and the generalization of the theoretical activities of the philosopher. In the optics of hermeneutics of a particular situation, of an individual with his speech and behavior, one must combine the pragmatic reduction of philosophizing and speculative sublimation of idiollect, the speech of the individual.

Interview respondent or participant of the case must appear as carriers of a complex structure of self-understanding, homologous to the subject of philosophizing, which must determine the logic of the experiment.

Particularly important is the attraction of philosophical tools to determine the first steps of the researcher, the development of the basic direction of the research, the analities of the axiological component of the measurement.

Conclusions. The study of the conditions of the applied turn of philosophical hermeneutics proved the fundamental importance of setting the problem of the synthesis of fundamental and applied science. The solution of the set tasks allowed to formulate the following provisions: 1) the theoretical conditions for the applied turn of philosophical hermeneutics include the pragmatic critique of the ontologization of the hermeneutic circle, that is, the reinterpretation of philosophical hermeneutics contrary to the key guidelines of its creators (M. Heidegger, H.-G. Gadamer; 2) key concepts and methods of philosophical hermeneutics, relevant to the measurement of actual social phenomena, there are a hermeneutic circle and self-understanding, hermeneutical reduction and destruction; 3) the logic of the applied use of the elements of philosophical hermeneutics in the context of social experiment involves the correlation of the structure of the study with the hermeneutic structure of selfunderstanding, inherent to the investigated subject.

\section{REFERENCES}

1. Bohachov A. (2013) Hermenevtychnyi pidhid u filosofii [Hermeneutic approach in philosophy], Filosofska Dumka, Vol. 5, pp. 41-50.

2. Bohachov A. (2011) Dosvid I sens [Experience and Sense]. Duh i Litera, Kyiv, 336 p.

3. Dakhniy A. Proekt hermenevtychnoi fenomnenolohii Martyna Haidegera v konteksti evoliutsii ioho myslennia [Martin Heidegger's Project of Hermeneutical Phenomenology in the Context of the Evolution of his Thinking], Sententiae, 2012, № 1 (XXVI), pp. 69-81.

4. Kebuladze V. (2013) Fenomenolohiia I hermenevtyka v suchasnyh ukrainskyh istoryko-filososkyh doslidzhenniah [Phenomenology and Hermeneutics in Contemporary Ukrainian Historic-Philosophical Research], Sententiae, pp. 138-146.

5. Shevchuk D. Hermenevtyka iak teoriya istorychnoho piznznnia: Vilhelm Diltei, Hustav Shpet [Hermeneutics as a theory of historical knoledge: Wilhelm Dilthey, Gustav Shpet]. Available at: http://kulturolog.org.ua/publications/p-article/326-2011-02-15-19-55-35.html. (Accessed on 08 September 2017).

6. Beetz M. Franzheld T. (2017). Qualitative hermeneutische Symbolanalyse: Methodische Probleme und sozialwissenschaftliche, Wiesbaden, Springer VS, 174 S. DOI 10.1007/978-3-658-14790-7_1

7. Fairfield P. (2011), Philosophical hermeneutics reinterpreted: dialogues with existentialism, pragmatism, critical theory, and postmodernism, Continuum, New York, $272 \mathrm{p}$.

8. Gadamer H. -G. (1990). Hermeneutik I: Wahrheit und Methode. - 1. Grundzüge einer philosophischen Hermeneutik. Tübingen, Mohr Siebeck, 508 S.

9. Heidegger M. (1977) Sein und Zeit. Gesamtausgabe. I. Abteilung: Veröffentlichte Schriften 1914-1970, Vittorio Klostermann, Frankfurt am Main, $600 \mathrm{~S}$.

10. Keane N. (ed) (2016) The Blackwell companion to hermeneutics, Wiley Blackwell, Oxford, $639 \mathrm{p}$.

11. Kögler H.-H. (2006), Hermeneutics, phenomenology and philosophical anthropology. In: Delanty G. (ed) Handbook of contemporary European social theory, Routledge, Abingdon, pp. 203-217. 